\title{
Gel-Forming Ability of Rohu as Affected by Egg White Powder Addition
}

\author{
Phatthira Sutloet ${ }^{1}$, Warangkana Sompongse ${ }^{1 *}$, Katsuji Morioka² \\ ${ }^{1}$ Department of Food Science and Technology, Faculty of Science and Technology, Thammasat University, Pathum Thani, Thailand \\ ${ }^{2}$ Aquatic Product Utilization Laboratory, Faculty of Agriculture, Kochi University, Nankoku, Japan \\ Email: faiiphat@gmail.com, *warang@tu.ac.th, morioka@kochi-u.ac.jp
}

How to cite this paper: Sutloet, P., Sompongse, W. and Morioka, K. (2019) GelForming Ability of Rohu as Affected by Egg White Powder Addition. Food and Nutrition Sciences, 10, 985-996. https://doi.org/10.4236/fns.2019.108070

Received: July 18, 2019

Accepted: August 16, 2019

Published: August 19, 2019

Copyright (c) 2019 by author(s) and Scientific Research Publishing Inc. This work is licensed under the Creative Commons Attribution International License (CC BY 4.0).

http://creativecommons.org/licenses/by/4.0/

(c) (i) Open Access

\begin{abstract}
The gel-forming ability of rohu (Labeo rohita) mince with and without egg white powder (EW) was investigated. Gel from washed mince (washed gel) was prepared under two setting conditions: kamaboko $\left(40^{\circ} \mathrm{C}\right)$ and modori $\left(60^{\circ} \mathrm{C}\right)$. The gel-forming ability of kamaboko and modori gels was improved by the addition of EW at $2 \%$. The autolytic inhibition of kamaboko gel was obtained in gel added with $2 \% \mathrm{EW}$, and $1 \%$ EW of modori gel. No marked change was observed in the TCA-soluble peptide content of either gel with the addition of EW above 1\%. No effect on the whiteness of both gels was shown after the addition of EW. The addition of EW exhibited smaller cavities and a more compact fibrous network in microstructure.
\end{abstract}

\section{Keywords}

Rohu (Labeo rohita), Gel-Forming Ability, Kamaboko Gel, Egg White Powder, Washed Gel

\section{Introduction}

The decline in marine fishery resources has affected mince/surimi production, and there have been attempts to utilize freshwater fish as an alternative, including Nile tilapia (Oreochromis niloticus) [1], red tilapia (Oreochromis niloticus $\times$ Oreochromis placidus) [2], common carp (Cyprinus carpio), and small-scale mud carp (Cirrhina microlepsis) [3]. Rohu (Labeo rohita) is a freshwater fish species that are widely aquacultured in Thailand. Based on the data for the year 2010, the amount of rohu produced in Thailand was 1167 tons, with a market value of 1.3 million US Dollars [4]. However, rohu contain small pin bones in their flesh, limiting their utilization. Processing the flesh to mince or for use as surimi would expand the range of utilization and market value. 
Gel-forming ability is one of the key determinants defining gel quality [2]. Fish muscle cleavage by endogenous protease activity is typically exhibited by the degradation of myofibrillar protein [5]. This degradation, and especially that of myosin, has an adverse effect on gel-forming ability, inhibiting the development of strong three-dimensional networks [6] [7]. Generally, gel weakening is induced at $50^{\circ} \mathrm{C}-70^{\circ} \mathrm{C}$ by endogenous thermal stable protease [8] [9]. This phenomenon is called modori. However, the activity of endogenous protease varies from species to species [10].

Egg white powder $(\mathrm{EW})$ is one of the food-grade inhibitors used to overcome the modori softening gel [11] [12]. EW contains ovomucoid, which inhibits trypsin, and ovoinhibitor, which inhibits trypsin and chymotrypsin [13]. It is used as a food ingredient because of its unique functional properties [14]. EW has also been used to improve gel quality [10] [11] [12], inhibiting the softening of the gel by acting as an enzyme inhibitor [10] [15]. Research has reported that the addition of EW improved the whiteness of surimi [16]. However, no study has reported on the addition of EW to the gel from rohu. Consequently, the objective of the present study was to investigate the effect of EW on the gel-forming ability of rohu (Labeo rohita).

\section{Materials and Methods}

\subsection{Materials}

Rohu (Labeo rohita), weighing $1000 \pm 100 \mathrm{~g}$ each, were purchased from Ying Charoen Market (Bangkok, Thailand). Fish were packed in an ice box and transported to the laboratory within $90 \mathrm{~min}$.

Egg white powder (EW) was purchased from Thai Food and Chemical Co., Ltd. (Thailand). Trichloroacetic acid (TCA) was purchased from QRëC (New Zealand). Folin-Ciocalteu's phenol was purchased from Merck KGaA (Darmstadt, Germany). Bovine serum albumin (BSA) was purchased from Sigma Chemical Co. (St. Louis, MO, USA). Reagents used for gel electrophoresis were purchased from Bio-Rad (Hercules, CA, USA).

\subsection{Methods}

\subsubsection{Preparation of Washed Minces}

The minced was prepared according to the method of [17]. The gutted and washed fillet was minced using a meat grinder ( $2 \mathrm{~mm}$ hole diameter; Kenwood, AT950A, England). Then, iced water was added at a ratio of 4:1 (w/w), the mixture was stirred for $5 \mathrm{~min}$ and left to stand without stirring for a further $5 \mathrm{~min}$. The temperature of the mixture was maintained below $10^{\circ} \mathrm{C}$ throughout the process. After that, the mixture was filtered through cheesecloth. The washing process was repeated three times, twice with iced water and the third time with cold $0.3 \%(\mathrm{w} / \mathrm{v})$ sodium chloride solution.

\subsubsection{Preparation of Washed Gels}

The procedure for preparation the gels from washed mince (washed gel) fol- 
lowed the method of [17]. Salt at $2.5 \%$ was added, and then EW at concentrations of $1 \%, 2 \%$, and $3 \%(\mathrm{w} / \mathrm{w})$ during grinding. Control is a gel without EW. The moisture content of gels was adjusted to $85 \%$ by the addition of iced water during grinding. The batter was stuffed into $2.5 \mathrm{~cm}$ diameter cellulose casing. The temperature of the batter was maintained below $12^{\circ} \mathrm{C}$ throughout the process. The kamaboko gel was heated at $40^{\circ} \mathrm{C}$ for $30 \mathrm{~min}$ followed by $90^{\circ} \mathrm{C}$ for $20 \mathrm{~min}$. The modori gel was heated at $60^{\circ} \mathrm{C}$ for $30 \mathrm{~min}$ then $90^{\circ} \mathrm{C}$ for $20 \mathrm{~min}$. All gels were immediately cooled in iced water until the core temperature of the samples fell below $10^{\circ} \mathrm{C}$ after heating. The samples were stored overnight at $4^{\circ} \mathrm{C}$ $\pm 2^{\circ} \mathrm{C}$ prior to further analysis.

\subsubsection{Folding Tests}

Slices with a thickness of $5 \mathrm{~mm}$ were cut from the $2.5 \mathrm{~cm}$ diameter cylinder shape, and folded into halves and quarters. The samples were evaluated followed the standard 5-point grade system [17].

\subsubsection{Determination of Textural Properties}

Gel samples were allowed to reach room temperature (approximately $30^{\circ} \mathrm{C}$ ). Five cylinder-shaped samples $2.5 \mathrm{~cm}$ in length were prepared from each gel. The textural properties of the gel samples were determined following the method of [17].

\subsubsection{Determination of Expressible Water Content}

Gel samples were cut into pieces of $0.5 \times 1 \times 0.5 \mathrm{~cm}$, and the expressible water content was measured following the method of [18].

$$
\text { Expressible water }(\%)=[(X-Y) / X] \times 100
$$

where, $X$ is the original weight and $Y$ is the weight after pressing.

\subsubsection{Determination of Whiteness}

Gel samples $2.5 \mathrm{~cm}$ in thickness and diameter were prepared, and their whiteness was determined using a colorimeter (ColorFlex CX2687, HunterLab, USA). D65 illuminant was used as the light source. CIE $L^{*}, a^{*}$, and $b^{*}$ values were measured. Whiteness was calculated using the following equation [19]:

$$
\text { Whiteness }=100-\left[\left(100-L^{*}\right) 2+a^{*} 2+b^{*} 2\right] 1 / 2
$$

\subsubsection{Determination of TCA-Soluble Peptide Content}

The TCA-soluble peptide content was measured by the method of [6] with slight modifications. Three grams of gel samples were homogenized with $27 \mathrm{ml}$ of cold $5 \%$ (w/v) TCA using ACE homogenizer (AM-8, Nissei, Japan). The homogenate was kept in ice for $1 \mathrm{~h}$ and then centrifuged at $8000 \times \mathrm{g}$ (MX-305, Tomy, Japan) for $10 \mathrm{~min}$ at $4^{\circ} \mathrm{C}$. Soluble peptides in the supernatant were determined following to the method of [20] and expressed as $\mu \mathrm{mol}$ tyrosine/g sample.

\subsubsection{SDS-Polyacrylamide Gel Electrophoresis (SDS-PAGE)}

SDS-PAGE was used to analyze the protein pattern of the gel samples using the 
method of [21]. Preparation of solubilized sample, stacking and separating gels and analyzing of protein pattern was carried out following the method of [17].

\subsubsection{Scanning Electron Microscopy (SEM)}

The microstructure of the samples was determined using a scanning electron microscope (JSM-IT300, JEOL, Japan). The specimens were fixed in $2.5 \%$ glutaraldehyde in $0.1 \mathrm{M}$ phosphate buffer $(\mathrm{pH} 7.2)$ for $2 \mathrm{~h}$. The specimens were rinsed twice with phosphate buffer and once with distilled water for $10 \mathrm{~min}$. After that the specimens were dehydrated with a graded series of ethanol $(30 \%, 50 \%, 70 \%$, $95 \%$, and $100 \% \mathrm{v} / \mathrm{v}$ ) for $10 \mathrm{~min}$. The samples were dried using a critical point dryer (Leica, EM CPD300, Austria), and were mounted and coated with gold (sputter coater, SCD 040, Bulzers, Germany).

\subsection{Statistical Analysis}

The experiment used a randomized complete block design. Data were subjected to analysis of variance. A Duncan's new multiple range test was used to determine the differences between sample means at $\mathrm{P} \leq 0.05$. All experiments were done in triplicate.

\section{Results and Discussion}

\subsection{Effect of EW on Textural Properties}

Figure 1 shows the result of the folding test and gel strength for washed gels containing EW at $0 \%-3 \%$. The addition of EW significantly affected the folding test of modori gel $(\mathrm{P} \leq 0.05)$, but not that of kamaboko gel. However, it significantly affected the gel strength of both modori and kamaboko gels $(\mathrm{P} \leq 0.05)$. As shown in Figure 1, the lowest folding test and gel strength were found in the modori control gel $(\mathrm{P} \leq 0.05)$, while the highest gel strength was observed in kamaboko gel with $2 \% \mathrm{EW}(\mathrm{P}>0.05)$. It appeared that setting at $60^{\circ} \mathrm{C}$ (modori condition) resulted in gel weakening, whereas setting at $40^{\circ} \mathrm{C}$ (kamaboko condition) resulting in gel strengthening. As gel set at $40^{\circ} \mathrm{C}$, endogenous transglutaminase (TGase) was activated, inducing cross-linking of $\varepsilon$-( $\gamma$-glutamyl) lysine in myosin heavy chain (MHC) via nondisulfide bonds [22]. In contrast, the weakening of modori gels was induced by endogenous protease. In a previous study on the degradation of washed gels, the lowest gel strength and maximum proteolytic activity in gel set at $60^{\circ} \mathrm{C}$ [17]. This supported the findings of [8] [9], who reported weakening of gel by endogenous protease under heating at $50^{\circ} \mathrm{C}$ $70^{\circ} \mathrm{C}$.

In the current study, gel strength increased as the concentration of EW was increased. In the case of kamaboko gel, the addition of $1 \%, 2 \%$, and 3\% EW increased the gel strength by $40.3 \%, 48.3 \%$, and $45.7 \%$ over than that of the control kamaboko gel. In the case of modori gel, the increase was $110.9 \%, 135.8 \%$, and $159.8 \%$, compared with that of control modori gel. The results were in accordance with those of [23], who reported that the gel strength of arrowtooth 


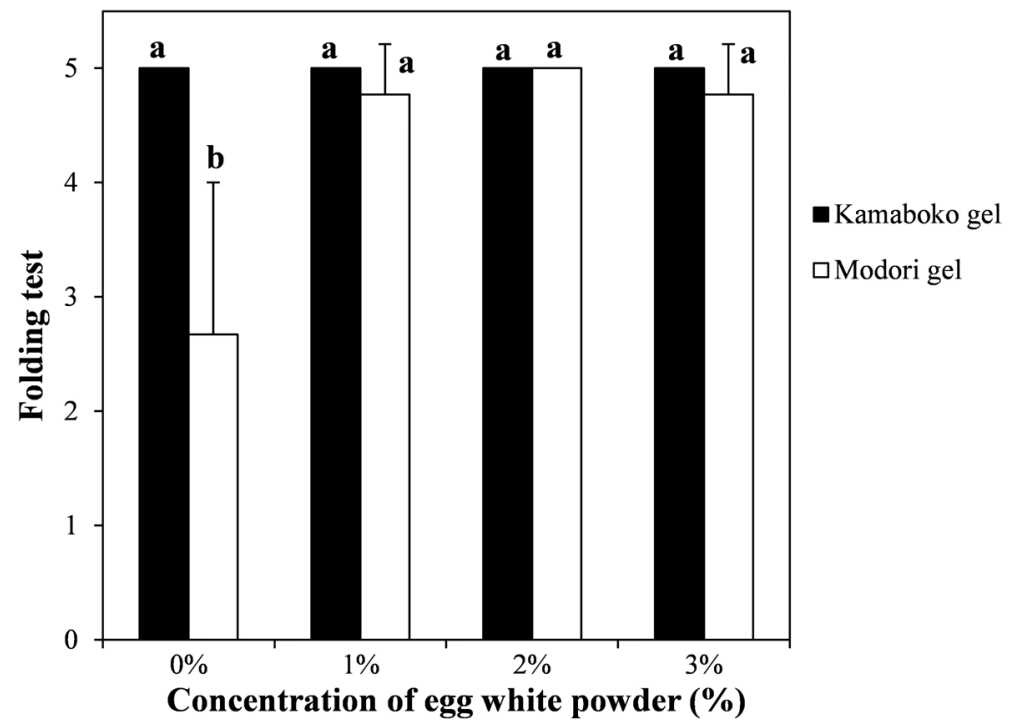

(a)

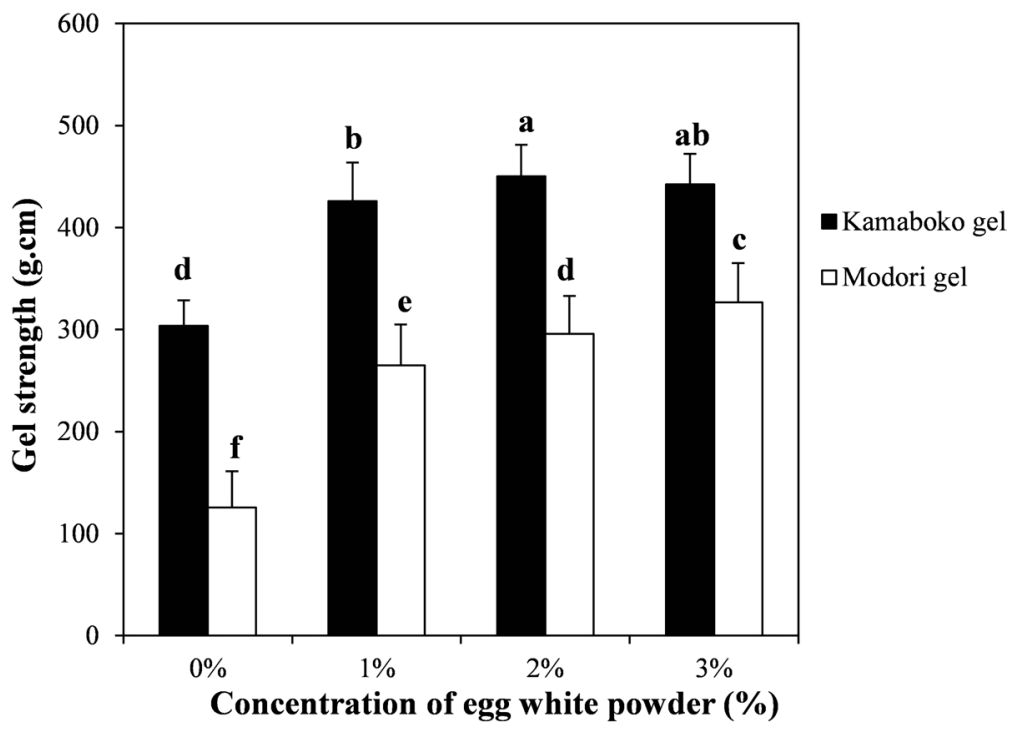

(b)

Figure 1. Effect of EW on textural properties of washed rohu gels. (a) folding test, and (b) gel strength. Bars represent the mean and standard deviation. Different letters on each bar indicate significant differences $(\mathrm{P} \leq 0.05)$.

flounder (Atheresthes stomias) and Alaska pollock (Theragra chalcogramma) surimi increased as the concentration of EW was increased to 2\%. [12] found that the addition of $3 \% \mathrm{EW}$ increased the breaking force and distance of common carp (Cyprinus carpio) surimi gel by $41 \%$ and $31 \%$, respectively, compared with a control. Overall these results suggested that the addition of EW improves the textural properties of gels. It might be due to the surface SH groups of EW protein. This enhance gel network formation by forming S-S bonds with other protein molecules [24] [25]. Moreover, [16], who study the interaction between egg white protein and fish protein from Alaska Pollock, found that the decrease in total SH groups corresponding with the increase in force and deformation 
value. Therefore, the improvement of gel strength in rohu gels was attributed to the covalent bonding of sulfhydryl groups. In addition, some proteinase inhibitors in EW have been reported to inhibit proteinases in lizardfish sarcoplasmic fluid. These include cystatin, ovoinhibitor, and ovomacroglobulin, which inhibit cysteine proteinase, serine proteinase, and aspartic proteinase, respectively [10] [15]. This demonstrated that improvement in the strength of the two gels in the present study was due to covalent bonding of sulfhydryl groups and proteinase inhibitor. In this study, the gel strength of $2 \% \mathrm{EW}$ modori gel was increased as equal to the kamaboko control gel. The result suggested that the addition of $2 \%$ EW improved the textural properties of both kamaboko and modori gels.

\subsection{Effect of EW on Expressible Water Content}

Figure 2 shows the expressible water content of washed gels at different levels of EW. The lowest content was observed in kamaboko gel with 3\% EW, though this was not significantly different from the $2 \%$ gel $(\mathrm{P}>0.05)$. The gel matrix with the lowest water-holding capacity, as shown by the highest expressible water, was that of the modori control gel. This result was in agreement with those for textural properties, indicating that the strong three-dimensional network of kamaboko gel can retain water within its structure. The expressible water content of both gels decreased as the concentration of EW was increased. For both gels, the lowest expressible water content was observed with $3 \% \mathrm{EW}$. In the case of kamaboko gel, the content was $24.2 \%$ less than control gel $(\mathrm{P} \leq 0.05)$. In modori gel, it was $37.6 \%$ less than control gel.

The modori gel had higher expressible water content than the kamaboko gel. The expressible water content of the modori control gel had $28.2 \%$ higher than that of the kamaboko control gel. As the concentration of EW increased, the

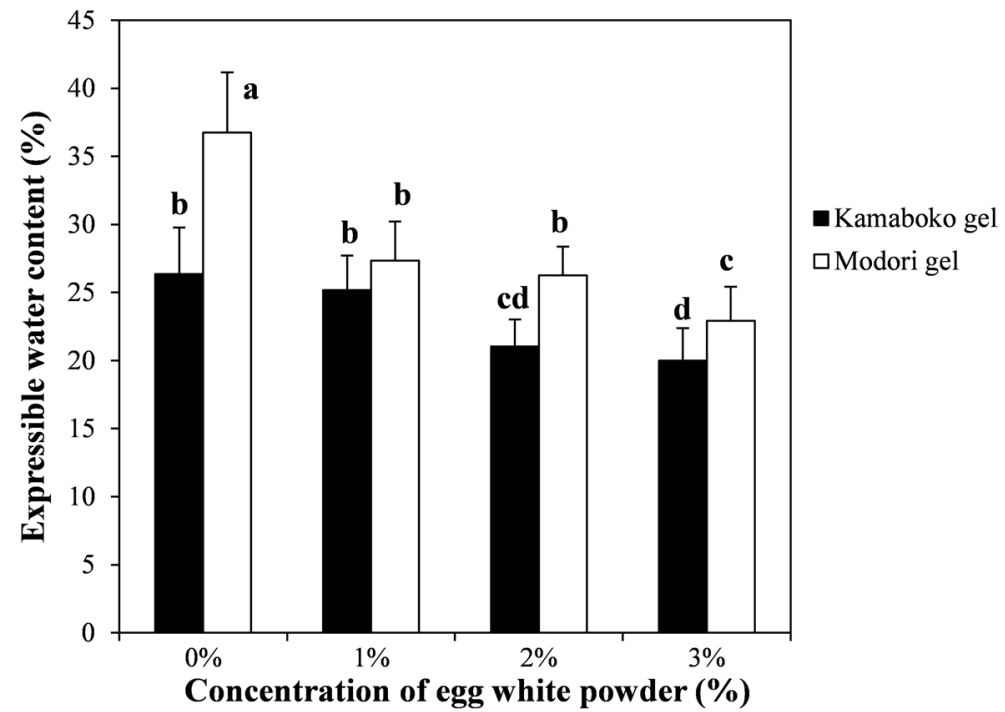

Figure 2. Effect of EW on expressible water content of washed rohu gels. Bars represent the mean and standard deviation. Different letters on each bar indicate significant differences $(P \leq 0.05)$. 
expressible water content decreased. This has been attributed to modori gel having a poor gel matrix with low water-holding capacity [26], which is improved by the addition of EW. In this study, the expressible water content of $1 \%$ and $2 \% \mathrm{EW}$ modori gel was decreased as equal to the kamaboko control gel. It was suggested that the addition of $2 \% \mathrm{EW}$ improved the water holding capacity of kamaboko gel and that of $1 \% \mathrm{EW}$ in modori gel.

\subsection{Effect of EW on Whiteness}

Figure 3 shows the whiteness of the washed gels containing EW at different levels. The whiteness of neither gel was significantly affected by the addition of EW (P > 0.05). As the concentration of EW was increased, the whiteness of gel did not increase. This might be because the washed gel was naturally white in color, and was not significantly lightened by the light cream of the EW. In addition, it appeared that the effect of modori gel was not different from that of the kamaboko gel, as compared in the same levels of EW $(\mathrm{P}>0.05)$. The result was in agreement with [10], which reported that the addition of EW had no effect on whiteness of lizardfish surimi gel prepared from different heating condition.

\subsection{Effect of Egg White Powder on TCA-Soluble Peptide Content}

Figure 4 shows the TCA-soluble peptide content of both washed gels at different levels of EW. The TCA-soluble peptide content of the kamaboko gel decreased by $38.2 \%, 39.4 \%$, and $52.5 \%$ with the addition of $1 \%, 2 \%$, and $3 \% \mathrm{EW}$, respectively, compared with that of the control gel. In the case of modori gel, the TCA-soluble peptide content decreased by $23.3 \%, 22.6 \%$, and $23.3 \%$, respectively. This supported the results from our previous studies, which suggested that the degradation of washed rohu gel was caused by serine protease [27]. Thus, the ovoinhibitor, one of the proteinase inhibitors in EW, could inhibit serine proteinase

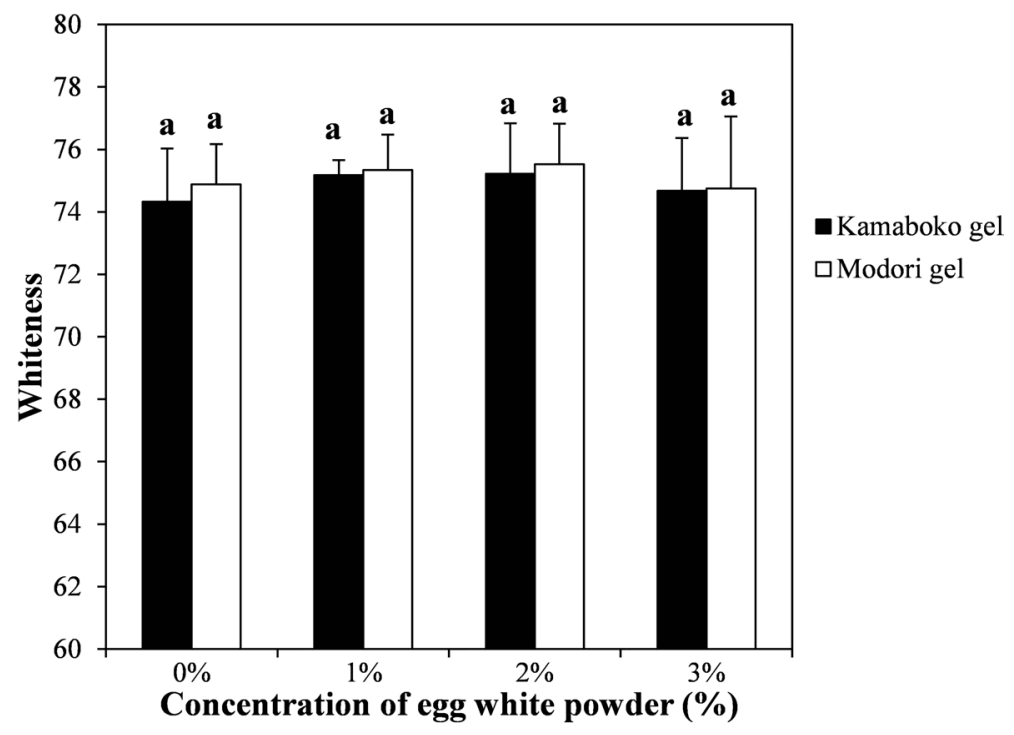

Figure 3. Effect of EW on whiteness of washed rohu gels. Bars represent the mean and standard deviation. Different letters on each bar indicate significant differences $(P \leq 0.05)$. 


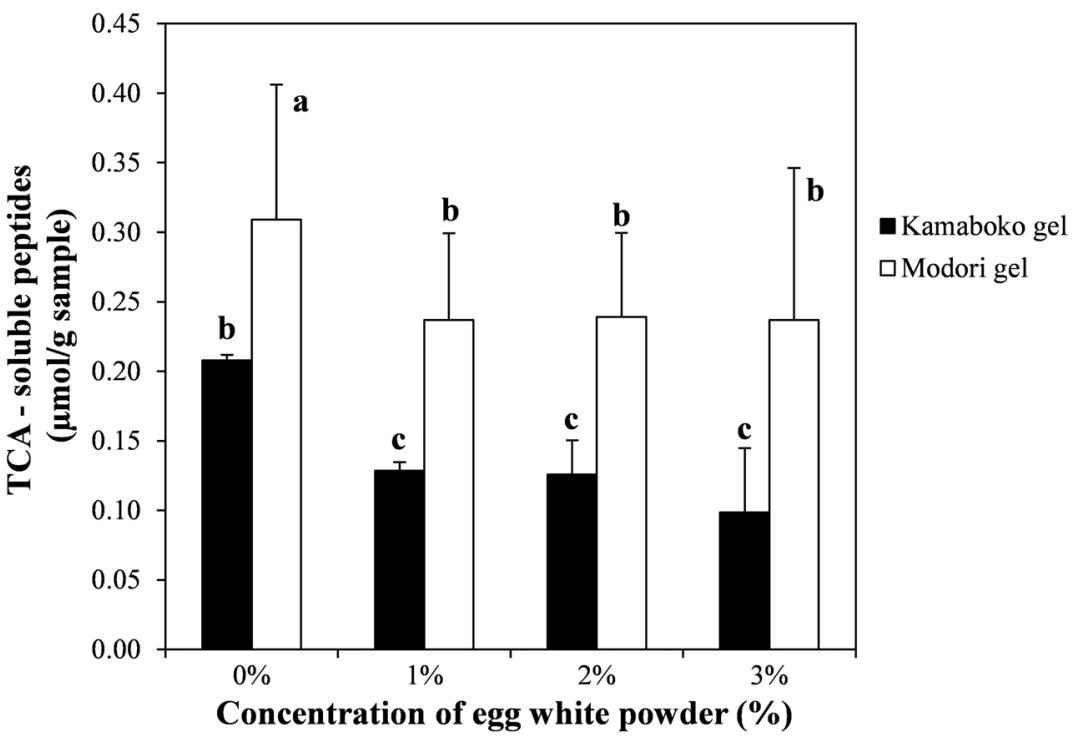

Figure 4. Effect of EW on TCA-soluble peptide content of washed rohu gels. Bars represent the mean and standard deviation. Different letters on each bar indicate significant differences $(\mathrm{P} \leq 0.05)$.

in washed rohu gel. However, the present study suggested that the addition of EW greater than $1 \%$ seem not to be necessary to prevent gel degradation of gel. The TCA-soluble peptide content of both gels was not in agreement with the textural properties, suggesting that the EW functioned more as a binder than as an inhibitor. Moreover, the content of the modori gel was higher than that of the kamaboko gel. This suggested that the degradation of the gel network was greater in the modori gel.

\subsection{Effect of EW on SDS-PAGE Profile}

Figure 5 shows the protein patterns of kamaboko and modori gels containing EW at different levels. The MHC intensity of the kamaboko control gel was slightly lower than that of the unheated control mince (Lane 2, Figure 5(a)), while the MHC band was slightly higher in gel with $2 \%$ and 3\% EW. In all kamaboko gels, the addition of EW had no effect on the intensity of degraded protein with molecular weights of $97-116 \mathrm{kDa}$, compared with that of kamaboko control gel (Lane 3, Figure 5(a)). In modori gel, the MHC band of the control gel was more severely degraded than that of the unheated control mince (Lane 2, Figure 5(b)). The addition of EW increased the intensity of the MHC band at all levels. These results coincided with the textural properties, and suggested that the degradation of both gels was prevented by the addition of EW. No change of actin band was observed for any gel.

\subsection{Effect of EW on Microstructure}

Figure 6 shows the microstructure of washed gels containing EW. Kamaboko gel without EW (Figure 6(a)) comprised a fibrous network with aggregation of packed protein, arranged as large clusters. As the concentration of EW was 
(a)

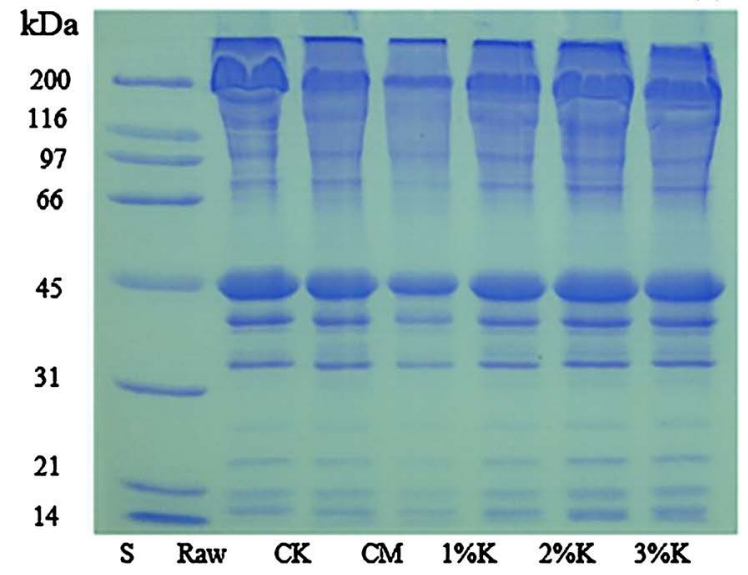

(b)

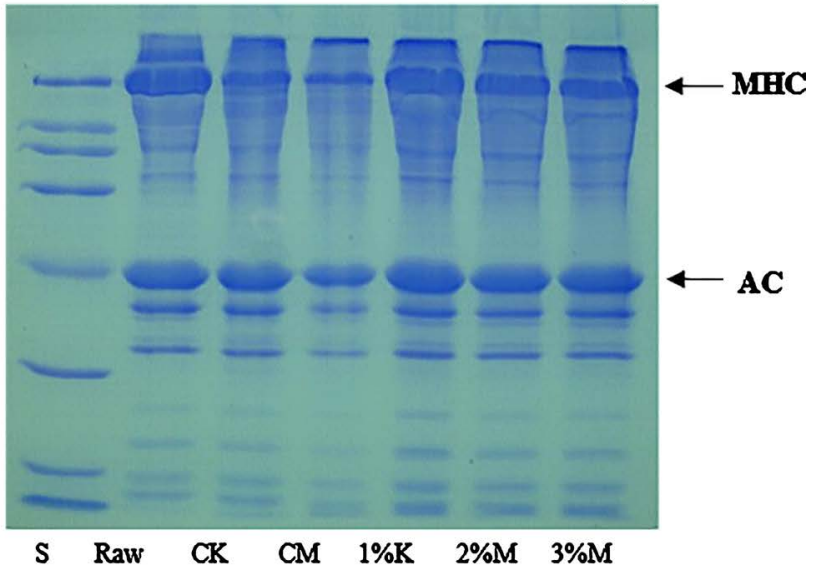

$\mathrm{K}$ is kamaboko gel and $\mathrm{M}$ is modori gel. MHC: myosin heavy chain; AC: actin; S: standard protein; R: raw sample (unheated control mince); CK: kamaboko control gel (without EW); CM: modori control gel (without EW); $1 \%-3 \% \mathrm{~K}$ : kamaboko gel with $1 \%, 2 \%$, and $3 \% \mathrm{EW} ; 1 \%-3 \% \mathrm{M}$ : modori gel with $1 \%, 2 \%$, and $3 \% \mathrm{EW}$.

Figure 5. Effect of EW on SDS-PAGE pattern of washed rohu gels. (a) SDS-PAGE pattern of kamaboko gel and (b) SDS-PAGE pattern of modori gel.
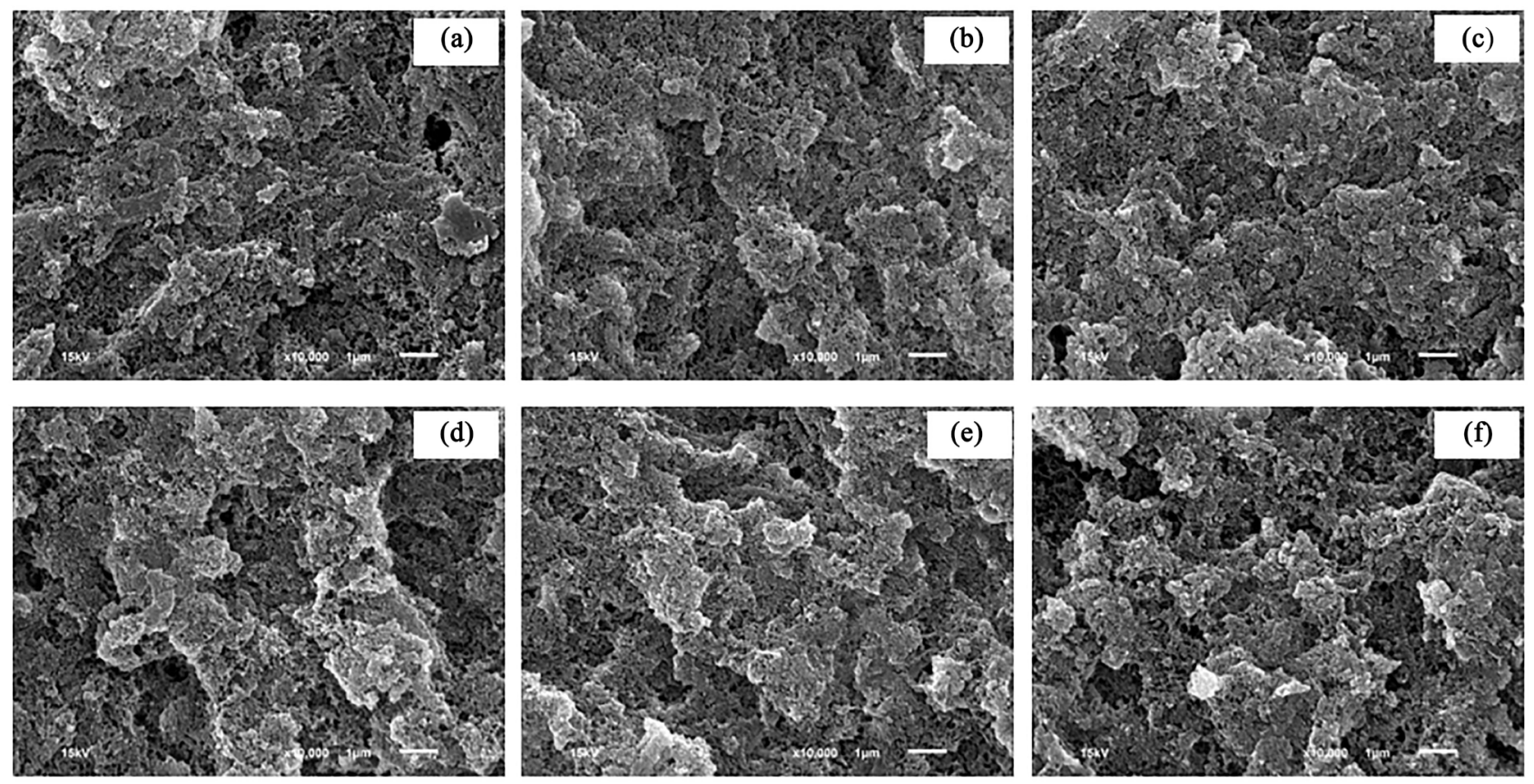

Figure 6. Effect of EW on microstructure of washed rohu gels. ((a)-(c)) kamaboko gel and ((d)-(f)) modori gel. (a) and (d): kamaboko and modori control gel (without EW), (b) and (e): gel with 1\% EW, (c) and (f): gel with 3\% EW. Magnification: 10,000×.

increased, the cavities decreased in size and the fibrous network became more compacted (Figure 6(b), Figure 6(c)). The gel with 3\% EW (Figure 6(c)) exhibited a clearly more compacted structure, compared with the control gel (Figure 6(a)). A fibrous network was also observed in the modori control gel (Figure 6(d)), but not as clearly. Whereas large cavities were found in the structure of the modori control gel, the gel with EW had a more compact structure with smaller cavities (Figure 6(e), Figure 6(f)). The modori gel with 3\% EW had a 
more clearly compacted structure than the control gel. The surface network of the kamaboko gel was smoother and more orderly than that of the modori gel. The higher gel strength of the kamaboko gel was attributed to this structure.

\section{Conclusion}

The addition of EW was demonstrated to improve the textural properties of washed gels, and to partially inhibit the proteolysis of modori gel. The gel-forming ability of kamaboko and modori gel was improved by the addition of $2 \%$ EW. For autolytic inhibition, the kamaboko gel was improved by the addition of EW at $2 \%$ and by the addition of $1 \% \mathrm{EW}$ in the modori. The degradation of MHC in washed gels was prevented by the addition of EW. The microstructure of both gels exhibited smaller protein clusters, and cavities, when EW was added.

\section{Acknowledgements}

This research was supported by the National Research Council of Thailand for the 2017 fiscal year. Financial support from Thammasat University through the Ph.D. scholarship is acknowledged.

\section{Conflicts of Interest}

The authors declare no conflicts of interest regarding the publication of this paper.

\section{References}

[1] Rawdkuen, S., Sai-Ut, S., Khamsorn, S., Chaijan, M. and Benjakul, S. (2009) Biochemical and Gelling Properties of Tilapia Surimi and Protein Recovered Using an Acid-Alkaline Process. Food Chemistry, 112, 112-119.

https://doi.org/10.1016/j.foodchem.2008.05.047

[2] Mahawanich, T., Lekhavichitr, J. and Duangmal, K. (2010) Gel Properties of Red Tilapia Surimi: Effects of Setting Condition, Fish Freshness and Frozen Storage. International Journal of Food Science and Technology, 45, 1777-1786. https://doi.org/10.1111/j.1365-2621.2010.02317.x

[3] Yongsawatdigul, J., Pivisan, S., Wongngam, W. and Benjakul, S. (2013) Gelation Characteristics of Mince and Washed Mince from Small-Scale Mud Carp and Common Carp. Journal of Aquatic Food Product Technology, 22, 460-473. https://doi.org/10.1080/10498850.2012.664251

[4] National Statistical Office of Thailand (2014) Products of Freshwater Fish Farm. http://service.nso.go.th/nso/nso_center/project/search_center/23project-th.html

[5] Choi, Y.J., Kang, I. and Lanier, T.C. (2005) Proteolytic Enzymes and Control in Surimi. In: Park, J.W., Ed., Surimi and Surimi Seafood, Taylor \& Francis Group, New York, 227-277. https://doi.org/10.1201/9781420028041.ch6

[6] Morrissey, M.T., Wu, J.W., Lin, D. and An, H. (1993) Protease Inhibitor Effects on Torsion Measurements and Autolysis of Pacific Whiting Surimi. Journal of Food Science, 58, 1050-1054. https://doi.org/10.1111/j.1365-2621.1993.tb06109.x

[7] Yongsawatdigul, J. and Piyadhammaviboon, P. (2004) Inhibition of Autolytic Activity of Lizardfish Surimi by Proteinase Inhibitors. Food Chemistry, 87, 447-455. https://doi.org/10.1016/j.foodchem.2003.12.019 
[8] Kinoshita, M., Toyohara, H. and Shimizu, Y. (1990) Diverse Distribution of Four Distinct Types of Modori (Gel Degradation)-Inducing Proteinases among Fish Species. Nippon Suisan Gakkaishi, 56, 1485-1492. https://doi.org/10.2331/suisan.56.1485

[9] An, H., Seymour, T.A., Wu, J. and Morrissey, M.T. (1994) Assay Systems and Characterization of Pacific Whiting (Merluccius productus) Protease. Journal of Food Science, 59, 277-281. https://doi.org/10.1111/j.1365-2621.1994.tb06947.x

[10] Benjakul, S., Visessanguan, W., Tueksuban, J. and Tanaka, M. (2004) Effect of Some Protein Additives on Proteolysis and Gel-Forming Ability of Lizardfish (Suarida tumbil). Food Hydrocolloids, 18, 395-401. https://doi.org/10.1016/S0268-005X(03)00127-9

[11] Rawdkuen, S., Benjakul, S., Visessanguan, W. and Lanier, T.C. (2007) Effect of Chicken Plasma Protein and Some Protein Additives on Proteolysis and Gel-Forming Ability of Sardine (Sardinella gibbosa) Surimi. Journal of Food Processing and Preservation, 31, 492-516. https://doi.org/10.1111/j.1745-4549.2007.00132.x

[12] Jafarpour, A., Hajiduan, H. and Rezaie, M. (2012) A Comparative Study on Effect of Egg White, Soy Protein Isolate and Potato Starch on Functional Properties of Common Carp (Cyprinus carpio) Surimi Gel. Journal of Food Processing and Technology, 3, 190. https://doi.org/10.4172/2157-7110.1000190

[13] Benjakul, S. (2006) Surimi: Science and Technology of Minced Fish Meat. O.S. Printing House, Bangkok.

[14] Campbell, L., Raikos, V. and Euston, S.R. (2003) Modification of Functional Properties of Egg-White Proteins. Nahrung, 47, 396-376. https://doi.org/10.1002/food.200390084

[15] Garcia-Carreno, F.L. and Hernandez-Cortes, P. (2000) Use of Protease Inhibitors in Seafood Products. In: Haard, N.F. and Simpson, B.K., Eds., Seafood Enzyme: Utilization and Influence on Postharvest Seafood Quality, Marcel Dekker, New York, 531-547.

[16] Hunt, A., Park, J.W. and Handa, A. (2009) Effect of Various Types of Egg White on Characteristics and Gelation of Fish Myofibrillar Protein. Journal of Food Science, 74, 683-692. https://doi.org/10.1111/j.1750-3841.2009.01354.x

[17] Sutloet, P., Sompongse, W. and Morioka, K. (2018) Effect of Setting Condition on Gel-Forming Ability of Rohu. Journal of Aquatic Food Product Technology, 27, 247-257. https://doi.org/10.1080/10498850.2018.1426068

[18] Sutloet, P., Sompongse, W. and Morioka, K. (2017) Effect of Whey Protein Concentrate on Gel-Forming Ability of Rohu (Labeo rohita). Journal of Advanced Agricultural Technologies, 4, 226-232. https://doi.org/10.18178/joaat.4.3.226-232

[19] Park, J.W. (1994) Functional Protein Additives in Surimi Gels. Journal of Food Science, 59, 525-527. https://doi.org/10.1111/j.1365-2621.1994.tb05554.x

[20] Lowry, O.H., Rosebrough, N.J., Farr, A.L. and Randall, R.J. (1951) Protein Measurement with the Folin Phenol Reagent. Journal of Biological Chemistry, 193, 265-275.

[21] Laemmli, U.K. (1970) Cleavage of Structural Proteins during the Assembly of the Head of Bacteriophage T4. Nature, 227, 680-685. https://doi.org/10.1038/227680a0

[22] Benjakul, S., Visessanguan, W. and Chantarasuwan, C. (2004) Effect of High-Temperature Setting on Gelling Characteristic of Surimi from Some Tropical Fish. International Journal of Food Science and Technology, 39, 617-680.

https://doi.org/10.1111/j.1365-2621.2004.00825.x 
[23] Reppond, K.D. and Babbit, J.K. (1993) Protease Inhibitors Affect Physical Properties of Arrowtooth Flounder and Walleye Pollock Surimi. Journal of Food Science, 58, 96-98. https://doi.org/10.1111/j.1365-2621.1993.tb03218.x

[24] Margoshes, B.A. (1990) Correlation of Protein Sulfhydryls with the Strength of Heat Formed Egg White Gel. Journal of Food Science, 55, 1753-1756. https://doi.org/10.1111/j.1365-2621.1990.tb03619.x

[25] Handa, A. and Kuroda, N. (1999) Functional Improvements in Dried Egg White through the Mailard Reaction. Journal of Agricultural and Food Chemistry, 47, 1845-1850. https://doi.org/10.1021/jf9811018

[26] Rawdkuen, S. and Benjakul, S. (2008) Whey Protein Concentrate: Autolysis Inhibition and Effects on the Gel Properties of Surimi Prepared from Tropical Fish. Food Chemistry, 160, 1077-1084. https://doi.org/10.1016/j.foodchem.2007.07.028

[27] Sutloet, P., Sompongse, W. and Morioka, K. (2018) Effect of Protease Inhibitors on Proteolytic Degradation of Rohu (Labeo rohita) Gel. International Journal of Food Science and Technology, 53, 2509-2514. https://doi.org/10.1111/ijfs.13844. 